\title{
Pengaruh Pelatihan Kerja Terhadap Kinerja Karyawan Melalui Kreativitas Pemecahan Masalah Sebagai Variabel Intervening (CV Deschino Sport)
}

\author{
Ardian Wahyunata \\ Fakultas Ekonomi, Universitas Sarjanawiyata Tamansiswa, Yogyakarta \\ Email : awahyunata@gmail.com
}

(Diterima: Juli 2021; Direvisi: Juli 2021; Dipublikasikan: September 2021)

\begin{abstract}
ABSTRAK
Penelitian ini menguji tentang hubungan antara Pelatihan Kerja, Kinerja Karyawan melalui Kreativitas Pemecahan Masalah. Metode yang peneliti gunakan adalah kuesioner dengan teknik sampel jenuh. Sampel dalam penelitian ini sebanyak 60 responden. Metode analisis menggunakan regresi dengan SPSS versi 17. Hasil Penelitian ini mendukung hipotesis yang di buat, yaitu, Pelatihan Kerja terhadap Kreativitas Pemecahan Masalah memiliki pengaruh positif, Pelatihan Kerja terhadap Kinerja Karyawan berpengaruh positif dan Kreativitas Pemecahan Masalah berpengaruh positif terhadap Kinerja Karyawan.
\end{abstract}

\section{Kata Kunci: Pelatihan Kerja, Kreativitas Pemecahan Masalah, Kinerja Karyawan}




\section{PENDAHULUAN}

Persaingan

berbagai

perusahaan dalam era global semakin kompleks, sehingga bagaimana strategi dari perusahaan yang harus dapat memperhatikan pemanfaatan seluruh potensi-potensi yang ada tak lain ialah Sumber Daya Manusianya, sehingga sebuah perusahaan nantinya dapat meningkatkan pemasukan dari pada perusahaan itu sendiri dan dapat meningkatkan kualitas mereka. Melihat pentingnya Sumber Daya Manusia di dalam organisasi maka pengelolaan sumber daya ini juga merupakan bagian yang sangat penting dari pekerjaan manajemen, mulai dari perekrutan karyawan, pelatihan, masa training, bekerja, penggajian serta yang lainnya.

Penelitian ini di lakukan pada CV. Deschino Sport di Bantul Yogyakarta yang merupakan produksi sarung tangan dengan pemasaran lokal hingga ekspor. Salah satu dari proses agar terciptanya tujuan dari perusahaan yaitu dengan Pelatihan Kerja. dalam Menurut Kaswan (2011:2) dalam (Sugiarti \& Megawarni, 2012), "Pelatihan kerja adalah proses meningkatkan pengetahuan dan ketrampilan karyawan,", Hal ini menunjukkakn pelatihan kerja sangat penting bagi tenaga kerja agar dapat lebih menguasai pekerjaan yang di berikan dan sebagai upaya mempersiapkan tenaga kerja dalam menghadapi tugas dalam perkerjaan.

Menurut Simamora dalam (Hartatik, 2014:89) dalam (Sugiarti et al., 2016), Upaya meningkatkan kinerja bagi karyawan dengan tujuan dilakukannya pelatihan kerja adalah untuk memperbaiki kinerja karyawan yang tidak memuaskan karena kekurangan keterampilan, sehingga dari beberapa pendapat di atas dapat disimpulkan bahwa pelatihan merupakan suatu proses peningkatan dalam pengetahuan dan unsur keahlian untuk memperbaiki kinerja karyawan dari yang kurang baik menjadi lebih baik, selanjutnya di tambah dengan unsur kreativitas yang tinggi telah di miliki oleh karyawan sehingga mampu dapat menyelesaikan permasalahan yang kreatif yang di harapkan, memang dapat dikatakan di dalam perusahaan banyak masalah yang akan di hadapi baik dengan karyawan perusahaan (internal) maupun hubungannya dengan pelanggan (eksternal), sehingga sumber daya manusia dituntut dapat memiliki ide-ide kreatif dalam menghadapi masalah di dalam suatu pekerjaan.

Menurut Hamalik, (1994:151) dalam (Wardani, 2020) problem solving adalah suatu proses mental dan intelektual dalam menemukan masalah dan memecahkan berdasarkan data dan informasi yang akurat, sehingga dapat diambil kesimpulan yang tepat dan cermat. Sehingga untuk meningkatkan Kinerja Karyawan dalam mencapai tujuan perusahaan di perlukan Pelatihan Kerja, karena memiliki peranan penting kualitas dari suatu karyawan, setelah diberikan Pelatihan Kerja maka timbullah suatu kreativitas bahkan inovasi atau ideide kreatif dari para karyawan dan dapat memecahkan masalah yang di hadapi dalam pekerjaan.

\section{TINJAUAN PUSTAKA}

\section{Pengertian Pelatihan Kerja}

Menurut Octaviani, 2019:11 dalam (Nurhelivia \& Wangdara, 
2020) "Pelatihan adalah bagian dari pendidikan yang menyangkut proses belajar untuk memperoleh dan meningkatkan keterampilan di luar sistem pendidikan yang berlaku, dalam waktu yang relatif singkat dengan metode yang lebih mengutamakan pelatihan dari pada teori", untuk dapat mendapatkan hasil yang memuaskan dari kinerja para karyawan sangat perlu adanya pengetahuan dan keterampilan yang cukup baginya. . Menurut Kaswan (2011:2) dalam (Sugiarti et al., 2016)," "Pelatihan adalah proses meningkatkan pengetahuan dan keterampilan karyawan."

Menurut Mangkunegara (2011: 57) dalam (Khoiriyah et al., n.d.), Indikator- indikator pelatihan tersebut yaitu : Instruktur, Peserta, Materi, Metode, tujuan.

a. Instruktur

Pentingnya kualitas dari seorang pelatih yang nantinya dapat menghasilkan orientasi pada peningkatan skill, sehingga bagian pelatih ini harus di perhatikan kualifikasikualifikasi yang memadai sesuai dengan bidangnya, personal dan kompetensi serta selain itu harus benar- benar baik untuk melakukan pelatihan.

b. Peserta

Dalam mengikuti
Pelatihan pesertanya juga
melalui proses seleksi
berdasarkan syarat-syarat
tertentu serta kualifikasi yang
sesuai, kemudian didalam
melakukan pelatihan harus
memiliki semangat yang tinggi
dalam mengikutinya.

\section{c. Materi}

Program pelatihan sumber daya manusia yang di berikan kepada para peserta baik dari materi maupun metode yang lainnya mempunyai manfaat yaitu tujuan yang hendak di capai oleh perusahaan. Materi pelatihan yang menyasar ke peserta di harapkan mampu menambah kemampuan peserta sehingga kedepan dapat diterapkan atau diaplikasikan ke dalam pekerjaannya nantinya

d. Metode

Memberikan sosialisasi metode pelatihan ini sebelumya agar peserta dapat mudah memahami apa yang telah di jelaskan oleh instruktur, dengan titik pencapaian memberikan pemahaman terhadap kebutuhan peserta pelatihan

e. Tujuan

Dengan pelatihan di harapkan para peserta atau calon karyawan baru memiliki hasil pelatihan kerja meliputi: meningkatnya skill dan ketrampilan, berbagai pengetahuan, dan tingkah laku karyawan.

\section{Kinerja Karyawan}

Menurut (Siagian, 2018: 5) dalam (Nurhelivia \& Wangdara, 2020) Kinerja berasal dari kata job performance yang berarti prestasi atau prestasi kerja oleh seseorang. Kinerja karyawan yaitu perolehan yang didapat dalam mengerjakan pekerjaan yang digapai seorang karyawan ketika dia melakukan pekerjaan dengan tanggung jawab yang ditugaskan. Pengertian 
kinerja (prestasi kerja) adalah hasil kerja yang berkualitas dan kuantitas yang dicapai karyawan dalam melaksanakan pekerjaan sesuai dengan apa yang telah diberikan oleh pimpinan perusahaan. Menurut Suparyadi (2015:300) dalam (Sari \& Susilo, 2020), kinerja karyawan merupakan masalah yang sentral dalam kehidupan sebuah organisasi karena sebuah organisasi atau perusahaan akan mampu mencapai tujuan atau tidak, sangat tergantung pada sebaik apa kinerja yang ditunjukkan oleh para karyawannya.

Menurut Menurut Bangun (2012:234) dalam (Sari \& Susilo, 2020), indikator dari penelitian kinerja karyawan yaitu: Kuantitas Pekerjaan, Kualitas Pekerjaan, Ketepatan Waktu, Kehadiran, Kemampuan Kerja Sama.

\section{Faktor- Faktor Kinerja Karyawan}

Menurut Mangkuprawira dan Hubeis (2007:160) (Anggereni, 2019) menyatakan bahwa kinerja karyawan dipengaruhi oleh faktor intrinsik dan ektrinsik karyawan sebagai berikut.

(1) Faktor intrinsik yang mempengaruhi kinerja pegawai terdiri dari pendidikan, pengalaman, motivasi, kesehatan, usia, keterampilan, emosi, dan spiritual.

(2) Faktor ekstrinsik yang mempengaruhi kinerja pegawai terdiri dari lingkungan fisik dan non fisik, kepemimpinan, komunikasi vertikal dan horizontal, kompensasi, kontrol berupa penyeliaan, fasilitas, pelatihan, beban kerja, prosedur kerja, sistem hukuman dan sebagainya.

\section{Tujuan dan Manfaat Kinerja Karyawan}

Tujuan dari dari kinerja menurut Mangkunegara (2014:10-11) dalam (Yulianti, 2015) adalah sebagai berikut:

a. Meningkatkan saling pengertian antara karyawan tentang persyaratan kinerja.

b. Mencatat dan mengakui hasil kerja seorang karyawan, sehingga mereka termotivasi untuk berbuat yang lebih baik, atau sekurangkurangnya berprestasi sama dengan prestasi yang terdahulu.

c. Memberikan peluang kepada karyawan untuk mendiskusikan keinginan dan aspirasinya dan meningkatkan kepedulian terhadap karier atau terhadap pekerjaan yang diembannya sekarang.

d. Mendefinisikan atau merumuskan kembali sasaran masa depan, sehingga karyawan termotivasi untuk berprestasi sesuai dengan potensinya.

\section{Kreativitas Penyelesaian Masalah} Menurut, (Sang-Woo Hahm 2018) dalam (Wardani, 2020) Kreativitas adalah generasi ide-ide baru dan berguna oleh masing-masing karyawan,sedangkan inovasi melibatkan sukses implementasi ideide kreatif oleh organisasi,sedangkan Menurut Rachmawati (2010:14) dalam (Styoro Cahyo Wibowo 2013), kreativitas merupakan suatu proses mental individu yang melahirkan gagasan, proses, metode ataupun produk baru yang efektif yang bersifat imajinatif, estetis, fleksibel, integrasi, suksesi, diskontinuitas, dan 
diferensiasi yang berdaya guna dalam berbagai bidang untuk pemecahan suatu masalah.

\section{Dimensi Kreativitas}

Kreativitas Menurut Rhodes dalam Munandar (2009) dalam (Sintaasih et al., 2013) mendefinisikan ke dalam 3 dimensi kreativitas yaitu; Person, Process, Press.I

\section{Point- point Penelitian Kreativitas}

Menurut Yilmaz \& Akman (2008:105) dalam (Sari \& Susilo, 2020), item dari penelitian kreativitas yaitu:

a. Didukung oleh manajemen dan budaya perusahaan yang mendorong untuk melakukan kreativitas.

b. Dapat beradaptasi terhadap perubahan lingkungan dengan cepat.

c. Melakukan perbaikan secara kontiyu untuk pengembangan kemampuan.

d. Didukung oleh manajemen untuk dapat mengetahui perubahan kondisi lingkungan.

e. Didukung oleh manajeman untuk berpartisipasi dalam aktivitas pengembangan perusahaan (produk, ide, kreativitas).

f. Menggunakan pengetahuan dari sumber informasi yang berbeda untuk mengembangkan tugas secara efisien dan efektif.

\section{Pengertian Penyelesaian Masalah (Problem Solving)}

Menurut Heppner dan

Krauskropf (Heppner,Pretorius, Lee \& Wang, 2002) dalam (Dwi et al.,
2016) pemecahan masalah dilakukan ketika individu menghadapi masalah kompleks, perubahan secara cepat, dan tujuan yang berhubungan secara langsung dengan kognitif, afektif, dan tindakan yang dilakukan untuk menghadapi masalah baik dari internal maupun eksternal individu.

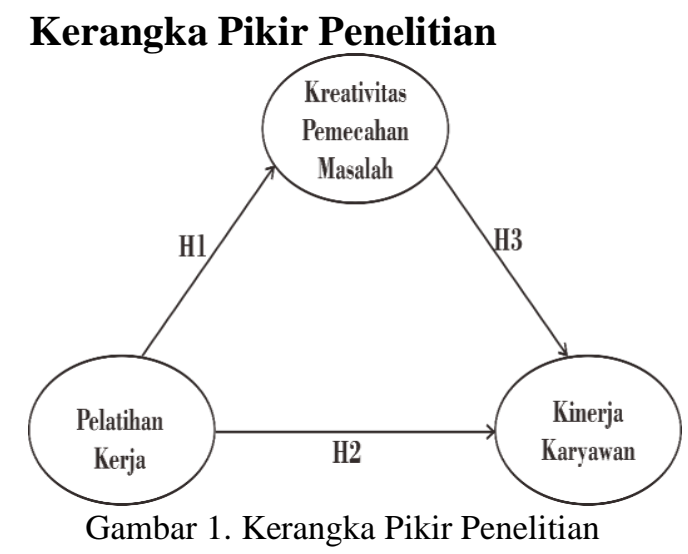

\section{METODE PENELITIAN}

Jenis penelitian yang di gunakan dalam penelitian ini adalah penelitian kuantitatif. Populasi dalam penelitian ini yaitu seluruh karyawan CV. Deschino Sport di Piyungan, Bantul, Yogyakarta yang berjumlah 60 orang. Dalam pengambilan Sampel ini menggunakan sampling jenuh yaitu Karyawan CV. Deschino Sport di Piyungan, Bantul, Yogyakarta sejumlah 60 karyawan. Data penelitian ini didapat dari individu atau perseorangan dengan cara mengisi kuesioner untuk mengetahui hasil dari penelitian ini menggunakan uji validitas, uji reliabilitas, uji asumsi kelasik, uji regresi dan uji sobel tes. Analisis data pada penelitian ini dilakukan dengan menggunakan bantuan komputer program SPSS versi 17. 


\section{HASIL PENELITIAN}

Jika $r$ hitung $>r$ tabel dan bernilai positif maka butir pernyataan atau pertanyaan pada kuesioner tersebut dapat dikatakan valid, begitu sebaliknya. Berikut hasil olah data dari 60 responden.

\section{Uji Validitas}

\section{Pengujian Validitas Pelatihan Kerja}

Tabel 1

Uji Validitas Variabel Pelatihan Kerja

\begin{tabular}{cccc}
\hline Butir & r hitung & r table & Keterangan \\
\hline PK.1 & 0,656 & 0,2542 & Valid \\
PK.2 & 0,638 & 0,2542 & Valid \\
PK.3 & 0,622 & 0,2542 & Valid \\
PK.4 & 0,556 & 0,2542 & Valid \\
PK.5 & 0,530 & 0,2542 & Valid \\
PK.6 & 0,574 & 0,2542 & Valid \\
PK.7 & 0,424 & 0,2542 & Valid \\
PK.8 & 0,616 & 0,2542 & Valid \\
PK.9 & 0,636 & 0,2542 & Valid \\
PK.10 & 0,423 & 0,2542 & Valid \\
PK.11 & 0,536 & 0,2542 & Valid \\
PK.12 & 0,650 & 0,2542 & Valid \\
PK.13 & 0,604 & 0,2542 & Valid \\
PK.14 & 0,499 & 0,2387 & Valid
\end{tabular}

Sumber: Data Primer Diolah, 2021

Pertanyaan Pelatihan Kerja terdiri dari 14 butir pertanyaan, berdasarkan hasil uji validitas seluruh item dinyatakan valid dengan nilai $r$ hitung bergerak dari 0,499 sampai dengan 0,656 , yang dibandingkan dengan nilai Tabel $r$ Product Moment sebesar 0,2542. Berdasarkan hasil analisis validitas, maka variabel Pelatihan Kerja dinyatakan Valid.

\section{Pengujian Validitas Kreativitas Pemecahan Masalah}

Tabel 2

Uji Validitas Variabel Kreativitas Pemecahan Masalah

\begin{tabular}{cccc}
\hline Butir & r hitung & r table & Keterangan \\
KPM.1 & 0,607 & 0,2542 & Valid \\
KPM.2 & 0,554 & 0,2542 & Valid \\
KPM.3 & 0,577 & 0,2542 & Valid \\
KPM.4 & 0,671 & 0,2542 & Valid \\
KPM.5 & 0,681 & 0,2542 & Valid \\
KPM.6 & 0,674 & 0,2542 & Valid \\
KPM.7 & 0,638 & 0,2542 & Valid \\
KPM.8 & 0,625 & 0,2542 & Valid \\
\hline
\end{tabular}

\begin{tabular}{cccc}
\hline KPM.9 & 0,650 & 0,2542 & Valid \\
KPM.10 & 0,625 & 0,2542 & Valid \\
KPM.11 & 0,627 & 0,2542 & Valid \\
KPM.12 & 0,671 & 0,2542 & Valid \\
KPM.13 & 0,624 & 0,2542 & Valid \\
KPM.14 & 0,666 & 0,2542 & Valid \\
KPM.15 & 0,571 & 0,2542 & Valid \\
\hline
\end{tabular}

Sumber: Data Primer Diolah, 2021

Pertanyaan Kreativitas

Pemecahan Masalah terdiri dari 15 butir pertanyaan, berdasarkan hasil uji validitas seluruh item dinyatakan valid dengan nilai $r$ hitung bergerak dari 0,554 sampai dengan 0,681 , yang dibandingkan dengan nilai Tabel $\mathrm{r}$ Product Moment sebesar 0,2542. Berdasarkan hasil analisis validitas, maka variabel Kreativitas Pemecahan Masalah dinyatakan Valid.

\section{Pengujian Validitas Kinerja Karyawan}

Tabel 3

Uji Validitas Variabel Kinerja Karyawan

\begin{tabular}{cccc}
\hline Butir & r hitung & r table & Keterangan \\
\hline KK.1 & 0,527 & 0,2542 & Valid \\
KK.2 & 0,581 & 0,2542 & Valid \\
KK.3 & 0,648 & 0,2542 & Valid \\
KK.4 & 0,720 & 0,2542 & Valid \\
KK.5 & 0,546 & 0,2542 & Valid \\
KK.6 & 0,595 & 0,2542 & Valid \\
KK.7 & 0,601 & 0,2542 & Valid \\
KK.8 & 0,632 & 0,2542 & Valid \\
KK.9 & 0,632 & 0,2542 & Valid \\
KK.10 & 0,627 & 0,2542 & Valid \\
\hline
\end{tabular}

Sumber: Data Primer Diolah, 2020

Pertanyaan Kinerja Karyawan terdiri dari 10 butir pertanyaan, berdasarkan hasil uji validitas seluruh item dinyatakan valid dengan nilai $r$ hitung bergerak dari 0,527 sampai dengan 0,720 , yang dibandingkan dengan nilai Tabel r Product Moment sebesar 0,2542

Berdasarkan hasil analisis validitas, maka variabel Kinerja Karyawan dinyatakan Valid. 


\section{Uji Reliabilitas}

Hal yang dilakukan setelah menunjukkan bahwa semua variabel pernyataan layak dijadikan instrumen penelitian adalah melakukan uji sampel besar sebanyak 60 responden. Pernyataan dapat di katakana reliabel jika nilai Cronbach's Alpha > 0.6. Berikut ini adalah hasil uji reliabilitas.

Tabel 4

Uji Reliabilitas

\begin{tabular}{lccc}
\hline Variabel & $\begin{array}{c}\text { Cronbach } \\
\text { 's Alpha }\end{array}$ & $\begin{array}{c}\mathbf{n} \\
\text { item }\end{array}$ & $\begin{array}{c}\text { Ketera } \\
\text { ngan }\end{array}$ \\
\hline $\begin{array}{l}\text { Pelatihan } \\
\text { Kerja }\end{array}$ & 0,834 & 14 & $\begin{array}{c}\text { Reliabe } \\
1\end{array}$ \\
\hline
\end{tabular}

\begin{tabular}{|c|c|c|c|}
\hline $\begin{array}{l}\text { Kreativitas } \\
\text { Pemechan } \\
\text { Masalah } \\
\text { Kinerja } \\
\text { Karyawan }\end{array}$ & 0,890 & 15 & $\begin{array}{c}\text { Reliabe } \\
1 \\
\text { Reliabe } \\
1\end{array}$ \\
\hline $\begin{array}{l}\text { Sumber: D } \\
\text { Ber } \\
\text { diambil } \\
\text { Chrobbac } \\
\text { 0,6. Mak } \\
\text { Kreativit } \\
\text { Kinerja } \\
\text { dan layak }\end{array}$ & $\begin{array}{l}\text { rimer D } \\
\text { arkan } \\
\text { impula } \\
\text { alpha } \\
\text { ariabel } \\
\text { emeca } \\
\text { yawan } \\
\text { unakar }\end{array}$ & $\begin{array}{l}202 \\
\text { ta } \\
\text { bah } \\
\text { ih } \\
\text { atih } \\
\text { Ma } \\
\text { alah }\end{array}$ & $\begin{array}{l}1 \text { dapat } \\
\text { a nilai } \\
\text { sar dari } \\
\text { Kerja, } \\
\text { lah dan } \\
\text { Reliabel }\end{array}$ \\
\hline
\end{tabular}

Persamaan 1

Tabel 5. Analisis Regresi

Coefficients $^{\mathrm{a}}$

\begin{tabular}{|c|c|c|c|c|}
\hline \multirow[t]{2}{*}{ Model } & \multicolumn{2}{|c|}{ Untandardized Coefficients } & Standardized & Sig \\
\hline & B & Std. Error & Beta & \\
\hline (Constant) & 1,903 & 6,547 & & $0,2910,771$ \\
\hline Pelatihan Kerja & 0,849 & 0,118 & 0,686 & $7,1880,000$ \\
\hline
\end{tabular}

a. Dependent Variable: Kreativitas

Pemecahan Masalah

Sumber : Data Primer Diolah, 2021

\section{Interpretasi analisis Regresi berganda}

Pada tabel diatas perhitungan regresi linier berganda dengan menggunakan program computer:

$\mathrm{KPM}=\mathrm{a}+\beta 1 \mathrm{PK}+\mathrm{e} 1$

Pada tabel diatas perhitungan regresi linier berganda dengan variabel Intervening sebagai berikut : $\mathrm{KPM}=1,903+0,849 \mathrm{PK}+\mathrm{e} 1$

Keterangan :

$\mathrm{KPM}=$
Kreativitas Pemecahan Masalah

PK = Pelatihan Kerja

1. Persamaan tersebut menunjukan bahwa setiap terjadinya kenaikan Pelatihan Kerja akan diikuti kenaikan Kreativitas Pemecahan Masalah sebesar 0,686 apabila variabel lain diasumsikan tetap. Semakain banyak Pelatihan Kerja maka semakin baik Kreativitas Pemecahan Masalah. 
Persamaan 2

Tabel 6. Analisis Regresi

Coefficients $^{\mathbf{a}}$

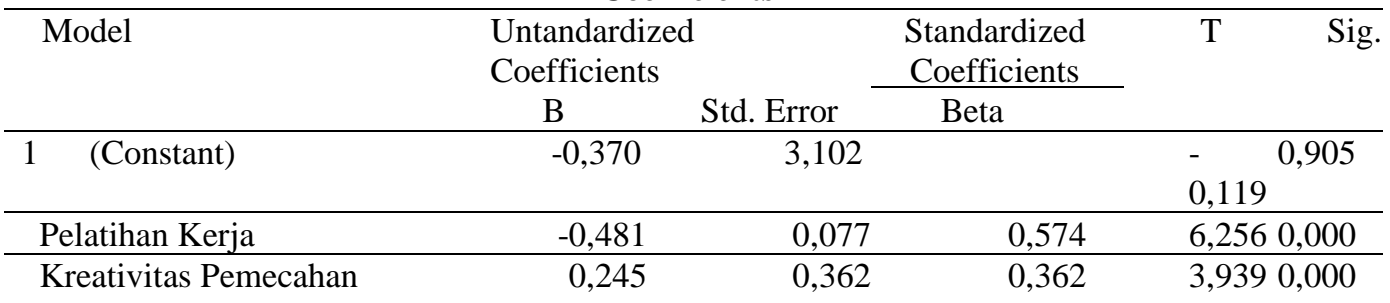

Masalah

b. Dependent Variable: Kinerja Karyawan Sumber : Data Primer Diolah, 2021

\section{Interpretasi analisis Regresi berganda}

Pada tabel diatas perhitungan regresi linier berganda dengan menggunakan program computer:

$\mathrm{KK}=\mathrm{a}+\beta 1 \mathrm{PK}+\beta 2 \mathrm{KPM}+\mathrm{e} 2$

Pada table diatas perhitungan regresi linier berganda dengan variabel Intervening sebagai berikut :

$\mathrm{KK}=(-0,370)+(-0,481) \mathrm{PK}+0,245$

$\mathrm{KPM}+\mathrm{e} 2$

Keterangan :

KK = Kinerja Karyawan

PK = Pelatihan Kerja

$\mathrm{KPM}=$ Kinerja Karyawan

1. Persamaan tersebut menunjukan bahwa setiap terjadi kenaikan Pelatihan Kerja akan diikuti kenaikan Kinerja Karyawan Sebesar 0,574 apabila variabel lain diasumsikan tetap. Semakin banyak Pelatihan Kerja maka semakin meningkat Kinerja Karyawan.

2. Setiap terjadi kenaikan Kreativitas Pemecahan Masalah akan diikuti kenaikan terhadap Kinerja Karyawan 0,362 apabila variabel lain diasumsikan tetap. Semakin banyak Kreativitas Pemecahan Masalah maka meningkat Kinerja Karyawan.

\section{Uji Hipotesis}

$\mathrm{t}$ hitung > $\mathrm{t}$ tabel $(7,188>$ 1,671). Sementara itu untuk nilai signifikansi yaitu sebesar 0,000 yang berarti lebih kecil dari 0,05 $(0,000<0,05$. Hal ini menunjukkan bahwa variabel Pelatihan kerja berpengaruh positif dan signifikan terhadap variabel Kreativitas Pemecahan Masalah, t hitung $>\mathrm{t}$ tabel $(6,256>1,671)$. Sementara itu untuk nilai signifikansi yaitu sebesar 0,000 yang berarti lebih kecil dari 0,05 $(0,000<0,05)$. Hal ini menunjukkan bahwa variabel Pelatihan Kerja berpengaruh positif secara signifikan terhadap variabel Kinerja Karyawan, $\mathrm{t}$ hitung > $\mathrm{t}$ tabel $(3,939>1,671)$. Sementara itu untuk nilai signifikansi yaitu sebesar 0,000 yang berarti lebih kecil dari 0,05 $(0,000<0,05)$. Hal ini menunjukkan bahwa variabel Kreativitas Pemecahan Masalah berpengaruh positif secara signifikan terhadap kinerja karyawan. 


\section{a. UJI F8}

Persamaan 1

Tabel 7. Hasil Uji F

ANOVA

\begin{tabular}{|c|c|c|c|c|c|c|}
\hline Mode & & $\begin{array}{l}\text { Sum of } \\
\text { Squares }\end{array}$ & Df & Man Square & $\mathrm{F}$ & Sig. \\
\hline \multirow[t]{3}{*}{1} & Regression & 1300,205 & 1 & 1300,205 & 51,669 & $0,000^{\mathrm{a}}$ \\
\hline & Residual & 1459,529 & 58 & 25,164 & & \\
\hline & Total & 354,515 & 59 & & & \\
\hline
\end{tabular}

a. Predictors : (Constant), Pelatihan Kerja

b. Dependent Variable : Kreativitas Pemecahan Masalah Sumber : Data Primer Diolah 2021

Dari hasil uji ANOVA atau F test menghasilkan nilai $\mathrm{F}$ hitung sebesar 51,669 dengan tingkat signifikansinya sebesar 0,000 atau

Persamaan 2

kurang dari 0,05 maka dapat disimpulkan bahwa Pelatihan Kerja berpengaruh terhadap Kreativitas Pemecahan Masalah

Tabel 8. Hasil uji $\mathrm{F}$

ANOVA b

\begin{tabular}{|c|c|c|c|c|c|c|}
\hline Model & & $\begin{array}{l}\text { Sum of } \\
\text { Squares }\end{array}$ & Df & Man Square & $\mathrm{F}$ & Sig. \\
\hline \multirow[t]{3}{*}{1} & Regression & 943,836 & 2 & 471,918 & 83,652 &, $000^{\mathrm{a}}$ \\
\hline & Residual & 321,564 & 57 & $\underline{5,641}$ & & \\
\hline & Total & $1,265,400$ & 59 & & & \\
\hline
\end{tabular}

a. Predictors : (Constant), Kreativitas Pemecahan Masalah, Pelatihan Kerja

b. Dependent Variable : Kinerja Karyawan

Sumber : Data Primer Diolah 2021

Dari hasil uji ANOVA atau F test menghasilkan nilai $\mathrm{F}$ hitung sebesar 83,652 dengan tingkat signifikansinya sebesar 0,000 atau kurang dari dari 0,05 maka dapat disimpulkan bahwa Pelatihan Kerja dan Kreativitas Pemecahan Masalah secara simultan berpengaruh terhadap Kinerja Karyawan.

\section{Koefisien Determinan $\left(\mathbf{R}^{2}\right)$}

Persamaan 1

Tabel 9. Hasil Uji Koefisien Determinan $\left(\mathrm{R}^{2}\right)$

Model Summary ${ }^{b}$

\begin{tabular}{ccccc}
\hline Model & $\mathrm{R}$ & R Square & $\begin{array}{c}\text { Adjusted R } \\
\text { Square }\end{array}$ & $\begin{array}{c}\text { Std. Error of the } \\
\text { Estimate }\end{array}$ \\
\hline 1 & $0,686^{\mathrm{a}}$ & 0,471 & 0,462 & 5,016 \\
\hline
\end{tabular}

a. Predictors: (Constant), Pelatihan Kerja

b. Dependent Variabel: Kreativitas Pemecahan Masalah

Sumber : Data Primer Diolah, 2021

Untuk mengetahui pengaruh variabel-variabel bebas secara serentak terhadap variabel tidak bebas dapat dilihat dari besarnya koefisien determinasi yang menunjukkan besarnya koefisien determinasi sebesar 0,642 yang menunjukkan variabel bebas secara bersama-sama mempengaruhi variabel tidak bebas sebesar $46,2 \%$ sisanya $53,8 \%$ dijelaskan oleh variabel lain yang 
tidak di teliti dalam model penelitian

ini.

Persamaan 2

Tabel 10. Hasil Uji Koefisien Determinan $\left(\mathrm{R}^{2}\right)$

Model Summary ${ }^{b}$

\begin{tabular}{ccccc}
\hline Model & $\mathrm{R}$ & $\mathrm{R}$ Square & $\begin{array}{c}\text { Adjusted R } \\
\text { Square }\end{array}$ & $\begin{array}{c}\text { Std. Error of the } \\
\text { Estimate }\end{array}$ \\
\hline 1 & $0,864^{\mathrm{a}}$ & 0,746 & 0,737 & 2,375 \\
\hline
\end{tabular}

a. Predictors: (Constant), Kreativitas Pemecahan Masalah, Pelatihan Kerja

b. Dependent Variabel: Kinerja Karyawan

Sumber : Data Primer Diolah, 2021

Untuk mengetahui pengaruh variabel-variabel bebas secara serentak terhadap variabel tidak bebas dapat dilihat dari besarnya koefisien determinasi yang menunjukkan baesarnya koefisien determinasi sebesar 0,737 yang menunjukkan variabel bebas secara bersama-sama mempengaruhi variabel tidak bebas sebesar $73,7 \%$ sisanya $26,3 \%$ dijelaskan oleh variabel lain yang tidak di teliti dalam model penelitian ini.

\section{PEMBAHASAN \\ Hipotesis 1}

Hasil uji hipotesis 1 dalam penelitian ini menunjukkan bahwa Pelatihan Kerja berpengaruh positif dan signifikan terhadap Kreativitas Pemecahan Masalah pada karyawan CV. Deschino Sport Piyungan Yogyakarta. Hasil ini di dukung analisis regresi dengan nilai thitung > $t$ tabel $(7,188>1,671)$. Sementara itu untuk nilai signifikansinya yaitu sebesar 0,001 yang berarti lebih kecil dari $0,05(0,001<0,05)$. Dengan demikian, artinya Pelatihan kerja mempunyai pengaruh yang positif dan signifikan terhadap Kreativitas Pemecahan Masalah pada karyawan CV. Deschino Sport di Piyungan, Bantul, Yogyakarta "Diterima". Berdasarkan uji diatas maka menunjukkan bahwa semakin banyak pelatihan di laksanakan perusahaan tersebut maka akan semakin tinggi juga kreatifitas dengan pemecahan masalah yang dilakukan oleh karyawan tersebut. Dengan di laksanakan Pelatihan Kerja dengan tujuan memberikan pengetahuan kepada karyawan, Pelatihan Kerja juga akan menekan tingkat kesalahan dalam karyawan bekerja, meningkatkan ketrampilan dan kemampuan karyawan sehingga mempunyai kualitas untuk pemecahan masalah secara kreatif. Hasil penelitian ini sesuai dengan penelitian oleh Leny dan Heru (2020) bahwa Pelatihan Kerja berpengaruh positif dan signifikan terhadap kreativitas pemecahan masalah.

\section{Hipotesis 2}

Hasil uji hipotesis kedua dalam penelitian ini menunjukkan bahwa Pelatihan Kerja berpengaruh positif dan signifikan terhadap kinerja karyawan CV. Deschino Sport Piyungan, Bantul, Yogyakarta. Hasil ini didukung analisis regresi dengan $\mathrm{t}$ hitung > t tabel $(6,256>1,671)$. Sementara itu untuk nilai signifikansinya sebesar 0,001 yang berarti lebih kecil dari 0,05 $(0,001<$ $0,05)$. Hal ini menunjukkan bahwa variabel Pelatihan Kerja berpengaruh positif terhadap Kinerja Kinerja Karyawan pada karyawan CV. Deschino Sport Piyungan, Bantul, 
Yogyakarta "Diterima". Berdasarkan uji diatas menunjukkan bahwa semakin sering diadakannya Pelatihan Kerja maka semakin tinggi juga Kinerja Karyawan di dalam perusahaan tersebut. Hasil penelitian ini sesuai dengan penelitian oleh $\mathrm{Ni}$ Wayan Eka (2018), Sugiarti, Tuti dan Hafniza (2016) bahwa Pelatihan Kerja berpengaruh positif dan signifikan terhadap Kinerja Karyawan

\section{Hipotesis 3}

Hasil uji hipotesis ketiga dalam penelitian ini menunjukkan bahwa Kreativitas Pemecahan Masalah berpengaruh positif terhadap Kinerja Karyawan pada CV. Deschino Sport di Piyungan, Bantul, Yogyakarta. Pada tabel dapat dilihat $\mathrm{t}$ hitung $>\mathrm{t}$ tabel $(3,939>1,671)$. Sementara itu untuk nilai signifikansi yaitu sebesar 0,001 yang berarti lebih kecil dari $0,05(0,001<0,05)$. Hal ini menunjukkan bahwa variabel Kreativitas Pemecahan Masalah secara signifikan terhadap Variabel Kinerja karyawan CV Deschino Sport di Piyungan, Bantul, Yogyakarta "Diterima". Berdasarkan uji diatas menunjukkan bahwa semakin tinggi kreativitas dalam hal pemecahan masalah atau ide- ide yang kreatif di tempat kerja maka akan mengakibatkan kenaikan juga pada Kinerja Karyawan dalam bekerja. Hasil penelitian ini sesuai dengan penelitian oleh Leny dan Heru (2020) dengan pengaruh positif antara Kreativitas Karyawan terhadap Kinerja Karyawan.

\section{Hipotesis 4}

Hasil Penelitian Pengaruh Pelatihan Kerja terhadap Kinerja Karyawan melalui Kreativitas Pemecahan Masalah. Berdasarkan uji sobel nilai One-tailed probability sebesar 0,001 yang berarti 0,001 < 0,05. Maka dapat ditarik kesimpulan untuk variabel pengaruh Pelatihan Kerja terhadap Kinerja Karyawan dengan Kreativitas Pemecahan masalah sebagai variabel pemediasi "Diterima". Berdasarkan uji diatas bahwa ada pangaruh antara Pelatihan Kerja terhadap Kinerja Karyawan pada CV Deschino Sport Piyungan, Bantul, Yogyakarta dengan berdasarkan jawaban dari karyawan $\mathrm{Cv}$ Deschino tersebut selaku responden dalam penelitian ini. Dengan Pelatihan Kerja yang di laksanakan oleh CV Deschino sport di Piyungan, Bantul, Yogyakarta dapat meningkatkan wawasan, pengetahuan serta ketrampilan sehingga dapat meningkatkan kreativitas dalam pemecahan masalah pekerjaan secara tepat sehingga membuat Kinerja Karyawan akan terus meningkat. Hasil penelitian ini sesuai dengan penelitian oleh Leny dan Heru (2020) dengan pengaruh tidak langsung Pelatihan Kerja terhadap Kinerja Karyawan melalui Kreativitas Pemecahan Masalah.

\section{KESIMPULAN}

1. Terdapat pengaruh positif dan signifikan Pelatihan Kerja dengan Kreativitas Pemecahan Masalah. Hal tersebut terbukti dengan nilai $t$ hitung $>\mathrm{t}$ tabel $(7,188>1,671)$ nilai probabilitas yaitu sebesar $(0,000)$ yang berarti lebih kecil dari signifikan 0,05 .

2. Terdapat pengaruh Positif dan signifikan Pelatihan Kerja dan Kinerja Karyawan. Hal tersebut terbukti dengan nilai $\mathrm{t}$ hitung $>\mathrm{t}$ tabel $(6,256>1,671)$ nilai probabilitasnya sebesar 0,000 yang 
berarti lebih kecil dari signifikan 0,05 .

3. Terdapat pengaruh positif dan signifikan Kreativitas pemecahan Masalah terhadap Kinerja Karyawan. Hal tersebut terbukti dengan nilai $\mathrm{t}$ hitung $>\mathrm{t}$ tabel ( $3,939>1,671) \quad$ nilai probabilitasnya sebesar 0,000 yang berarti lebih kecil dari signifikan 0,05 .

\section{DAFTAR PUSTAKA}

Anggereni, N. W. E. S. (2019). Pengaruh Pelatihan Terhadap Kinerja Karyawan Pada Lembaga Perkreditan Desa (Lpd) Kabupaten Buleleng. Jurnal Pendidikan Ekonomi Undiksha, $\quad$ 10(2), 606. https://doi.org/10.23887/jjpe.v1 0i2.20139

Dwi, D., Rahmah, N., \& Fahmie, A. (2016). Pengaruh Pelatihan Coaching Terhadap Kemampuan Pemecahan Masalah Pada Supervisor The Effectiveness Of Coaching Training On Problem Solving Ability Among Supervisors Dalam beberapa tahun terakhir, industri batu bara mengalami kelesuan akibat adanya krisis. Jurnal Intervensi Psikologi, 8(2), 263-284. https://media.neliti.com/media/ publications/101970-IDpengaruh-pelatihan-coachingterhadap-kem.pdf

Khoiriyah, Y., Arifin, R., \& Mustapita, A. F. (n.d.). Pengaruh Lingkungan Kerja, Pelatihan, Motivasi Dan Komitmen Organisasi Terhadap Kinerja Pegawai Tata Usaha Sekretariat Daerah
Kabupaten Malang. 200-212.

Nurhelivia, N., \& Wangdara, Y. (2020). Pengaruh Pelatihan Dan Motivasi Kerja Terhadap Kinerja Karyawan Pada Pt Osi Electronics. Scientia Journal: Jurnal Ilmiah http://113.212.163.133/index.p $\mathrm{hp} /$ scientia_journal/article/view 12282

Sari, L. A., \& Susilo, H. (2020). Pengaruh Pelatihan Kerja Terhadap Kinerja Karyawan Dengan Kreavitas Sebagai Variabel Interverning (Studi Pada Karyawan BRI Kantor Cabang Kawi Malang). Jurnal Administrasi Bisnis, 78(1), 130-139.

Sintaasih, D. K., Indrawati, A. D., Bgs, I. G., \& Satrya, H. (2013). Kreativitas Sebagai Mediator Pengaruh Pemberdayaan Pada Kinerja Pengelola Lembaga Perkreditan Desa (Lpd) Di Kabupaten Gianyar. 5-13.

Styoro Cahyo Wibowo, A. (2013). Pengaruh Pelatihan Dan Kreativitas Terhadapkinerja Karyawan Bagian Teknisi Pada Pt. Perusahaan Listrik Negara (Persero)Area Bojonegoro. Jurnal Ilmu Manajemen (JIM), 1(4).

Sugiarti, H., \& Megawarni, A. (2012). Konsistensi koefisien determinasi sebagai ukuran kesesuaian model pada regresi robust. Matematika, Sains, Dan Teknologi, 13(2), 65-72. http://jurnal.ut.ac.id/index.php/ JMST/article/view/448/380

Sugiarti, Hartati, T., \& Amir, H. (2016). Pengaruh Pelatihan Kerja terhadap Kinerja Karyawan pada PT Padma 
Ardya Aktuaria Jakarta. Jurnal Epigram Vol. 13 No. 1 April, 13(1), 13-20. http://jurnal.pnj.ac.id/index.php /epigram/article/download/805/ 513

Wardani, N. W. (2020). Analisis Pengaruh Empowerment Leadership Terhadap Creative Problem Solving Dengan Mediasi Dynamic Exploration
Capability Studi di PT . Casuarina Harnessindo Pemalang.

Yulianti, E. (2015). Pengaruh Pelatihan Terhadap Kinerja Karyawan Grand Fatma Hotel Di Tenggarong Kutai Kartanegara. Journal Administrasi

BisnisAdministrasi Bisnis, 3(4), 904. 